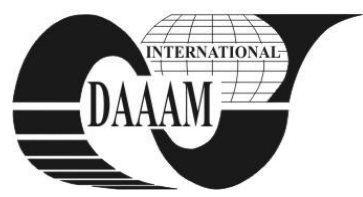

Annals of DAAAM for 2011 \& Proceedings of the 22nd International DAAAM Symposium, Volume 22, No. 1, ISSN 1726-9679 ISBN 978-3-901509-83-4, Editor B. Katalinic, Published by DAAAM International, Vienna, Austria, EU, 2011 Make Harmony between Technology and Nature, and Your Mind will Fly Free as a Bird Annals \& Proceedings of DAAAM International 2011

\title{
THE MANAGER ROLE IN DECISION MAKING
}

\author{
KURTUHUZ, A[ndreea] M[aria]; VASILESCU, I[on]; LUPU, F[elicia]; LUPU, A[drian] G[elu]; \\ RADU, D[aniela] L[iana] \& KURTUHUZ, M[arcel] C[odrut]
}

\begin{abstract}
Consequently, one of characteristic in organization is taking decision, and of course, it is one of manager's activities. To be able to compete with their competitors, a profit organization should consider making a quick right decision. Although it is hard but possible to achieve as long as the managers able to avoid some blunders that may lead a decision to err. For that reason, there is a need to understand the processes of how a decision being produced. Managers make decisions every day that affect their team and their organization. Before any manager makes a decision, they first need to define their goals. You need to examine if the decision is the right decision and how you can get commitment from your staff to implement the decision you have made.

Key words: managerial decisions, leadership, management teams
\end{abstract}

\section{INTRODUCTION}

Usually a manager must multi-task, keep focused on reaching goals, keep employees motivated, and make decisions that will affect the financial health of a company without all the information needed to make the decision. What is a manager supposed to do?

\section{THE MAN MAKING DECISIONS}

Leadership is all about decision making. As a leader you must decide the what, where, why and who for your organization. Effective decision making leads to success for the organization and by extension for the leader. If you take a look at the history of countries and organizations, most failures have been the result of faulty decisions by the person in charge.

Before any decision can be made, a manager must have the authority to do so. Most companies have clearly delegated and documented authorities for making financial and human resource decisions. Day-to-day operational decisions, such as what time breaks are to be taken, are usually assumed as part of the role and inferred by responsibilities in the main position description.

A manager has the responsibility to make decisions that need to be made. If you are indecisive, it will appear that you cannot make the tough choices or take a stand on issues that affect the organization. Managers need not to be concerned that taking a stand on an issue will cause others to dislike them, it is impossible for everyone to like you anyway. Usually if someone rejects your opinion, they are rejecting your point of view; they are not rejecting you as a professional or person.

If there is one quality that distinguishes a good manager from a poor one, it is decisiveness. A person in managerial position who is poor in decision making is fit to be called only an administrator and not a manager. Good decisions require an element of judgment. A decision made with too little information can have an unexpected and unwelcome outcome.
While delaying a decision for too long to obtain all possible information can render the decision ineffective. The more information we have the better prepared we are to make effective decisions and the less likely it is that we will be surprised by an unforeseen outcome. We need to gather as much relevant information as possible within the timeframe avaible.

\section{THE MANAGEMENT TEAM PERFORMANCE}

Different decisions require different approaches and the good manager will demonstrate the ability to change according to the needs of each decision. Budget decisions are in some respects easier because you have hard facts and costs in versus costs out. You should ensure that costs out never exceed costs in unless you are certain there will be long term cost-effective results and this can be hard. Personal issues represent a trickier area because you will also know which of your colleagues and workers are of more value to a company. It is a hard fact that some employees benefit companies more than others and where there is a dispute it is often easy for a manager to come down firstly on the side of the employee who appears more beneficial but your role is not always clear cut and you first need to decide why the issue has come your way in the first place.

Management teams are responsible for decision-making and the decisions they make will influence the overall performance of the organization. High performing management teams require members who will not partake in the management of an organization in the form of a drone. In other words, management must be willing to voice opinions constructively. With this understood, conflict will undoubtedly arise in the management team, both functional and dysfunctional.

The form of conflict that is productive is cognitive conflict, which is "task oriented and focused on discussing and challenging diverse perspectives" (Amason \& Mooney, 1999; p. 341). The opposite form of conflict is affective conflict, which is more emotional based. When considering conflict, the key to ensuring a high performing management team is making sure that conflict is of the cognitive variety, based on critical thinking and focused on tasks, while removing the affective conflict, that which is based on emotion.

Another important consideration is leadership behavior and its "effects on subordinates, including how they relate both to the leader as well as to each other" (Flood, et. al., 2007, p. 403; Bass; 2011).

Four main leadership styles, from the perspective of behavior, can play a role in high performing managers. These include transactional, transformation, empowering, and directive leadership styles (Flood, et. al., 2007; Bass; 1990). The first three styles are viewed as being associated with teamwork, or empowerment. These styles have the propensity to have a positive impact on communication within the team as 
well as throughout the organization (Flood, et. al., 2007; French, Morrison \& Leoinger, 1960; Kirmeyer \& Lin; 1987).

These four leadership styles characterize different management behavoiurs (Flood, et. al., 2007):

- Authoritarian - leader of this style will likely impair the quality of work by others and communication (Hambrick \& D'Aveni, 1992). Other teams members will likely not offer input or assert power in their respective positions because this style can act as a roadblock.

- Transactional Leaders -who influence others by appealing to their interest via the use of rewards (Burns, 2010).

- Transformational -this leader motivates followers to go beyond the original expectations, striving for higher outcomes (Burns, 2010).

- Laissez Faire -this is a passive leadership style in which leaders take measures to avoid decisionmaking and supervisory responsibility (Den Hartog, Van Muijen \& Koopman, 1997).

By these simple assessments of leadership style, the reader can establish the significance on a leadership team. A poor leadership style will translate into a leadership team in disarray.

\section{DECISIONS MAKING PROCESS}

The key to making good decisions is to have a sound process or series of steps from start to finish. A study of leadership and management texts provides a number of processes from a simple three-step process to as many as seven steps. A process is a series of steps that are interrelated and follow a specific methodology. The four steps are:

- Define the problem

In getting any job done, it is best to start at the beginning. The first step in making a decision is to have a clear understanding of the problem that is to be solved. This could be thought of as The Job to Be Done. In this part of the process you establish the context of the problem and set goals. It is extremely important to have a clear understanding of what you are trying to decide. This is the step in the process where you must determine if, in fact, any action is needed. Don't waste time trying to solve problems that don't need to be solved, keeping in mind that not doing anything is in itself a decision.

\section{- Gather information}

During this step in the process, we determine what information or data is applicable to the job to be done. Information gathering can be done through research, experimentation or brainstorming. It is important during the information gathering phase to consult with all actors who have equity in the problem to be solved. As data is accumulated, it should be evaluated for its impact, positive or negative, on the problem at hand. Be aware during this phase of how your cognitive and personal biases affect how or even whether you take in information. Your cognitive preference, whether you are intuitive or analytical, will determine what types of information you prefer and how you prefer to receive it. Be aware of this so that you are can take full advantage of the total range of information that is potentially available. It is also essential not to let personal bias distort data. We all have a human tendency to prefer information from sources we like, and to want avoid information from those we dislike or distrust. If your decisions are to be effective, you must be aware of your personal feelings and seek ways to mitigate their effect on your assessment of the information that is presented to you.
- $\quad$ List and evaluate alternatives

In the military planning process, analysis of course of action (COA) is an essential element of preparation of battle plans and campaigns. Several possible COAs are developed for each mission, which are then carefully analyzed for presentation to the commander's final decision. The costs, benefits and collateral (second and third order effects) impact are compared, along with all known potential obstacles to achieving the desired outcome. It is useful during this step to list the courses of action side by side and conduct a plus/minus review of advantages and disadvantages. The objective is to develop that course that is the "best" solution for the problem; the solution that gets the job done with optimum results and best use of available resources.

- Chose and implement a course of action

This is where the rubber meets the road. A decision is made. During the implementation phase of the process, you should constantly evaluate progress and make adjustments as necessary, keeping the desired end state firmly in mind. If necessary, go back to step one and review the job to be done, or goal, to make sure you have fully understood what your objective is.

\section{CONCLUSION}

Managers, in-order to make good decisions need to follow a simple format. To be effective managers must get a good understanding of the challenge they must meet. Whether the decision is about a staff roster or a major investment in technology it should be based on relevant information, involve input from the right people and have all the elements of a good decision. By understanding these elements, managers and leaders alike are in a better position to act as a cohesive decision making unit, which translates into success for the organization.

\section{REFERENCES}

Amason, A.C. \& Schweiger, D.M. (1994). Resolving the Paradox of Conflict, Strategic Decision Making and Organizational Performance. International Journal of Conflict Management, Vol.5, Iss.3, p.239-253, ISSN 10444068

Amason, A. \& Mooney, A. (1999). The Effects of Past Performance on Top Management Team Conflict in Strategic Decision Making. International Journal of Conflict Management, Vol.10, Iss.4, p.340-359, ISSN $1044-4068$

Bass, B. (2011). Bass \& Stogdill's Handbook of Leadership: Theory, Research and Managerial Applications (5rd ed.). New York: Free Press

Burns, J.M. (2010). Leadership. New York: Harper \& Row

Flood, P., Hannan, E., Smith, K., Turner, T., West, M., \& Dawson, J. (2007). Chief executive leadership style, consensus decision making, and topmanagement team effectiveness. European Journal of Work \& Organizational Psychology, Vol.13, No.3, (2007, September), p.401-420, ISSN 1359-4323

Den Hartog, D., Van Muijen, J., \& Koopman, P. (1997). Transactional Versus Transformational Leadership: An Analysis of the MLQ. Journal of Occupational and Organizational Psychology, Vol.70, (March, 1997), p.1934, ISSN 0963-1798 